\title{
Award now, pay later
}

\section{London}

UNIVERSITIES that win grants from the UK Science and Engineering Research Council (SERC) may be forced to borrow money to buy equipment and hire research assistants, under a new SERC policy that is designed to relieve the council's immediate financial difficulties.

The reason is that SERC, in its latest round of grants, has imposed strict limits on what percentage of a grant can be spent in its first two years. The details vary from project to project, but some researchers will be given only 15 per cent of a three year grant to spend in the first year. In some cases, SERC intends to hold back more than 50 per cent of a grant until the final year of the project.

This, however, is precisely the opposite of the way that many researchers need their grants to be structured. Grant recipients often need to spend a large proportion of their awards in the first two years of a project, particularly when expensive items of equipment must be purchased. SERC's policy, therefore, will force universities to borrow money to cover the start-up costs of research projects, says David Thomas, industrial liaison officer at Imperial College, London, who is also responsible for Imperial's income from the research councils.
Thomas fears that the policy could "change the criteria by which grants are awarded". Rather than the best projects being funded, he believes grants may go to the richer universities, or those that are prepared to slip into debt. Jim Reed, industrial liaison officer at the University of Surrey, is now conducting a survey of his colleagues around the country to gauge the extent of the difficulties the new policy will bring for the universities.

SERC officials say that the spending limits will help relieve SERC's well publicized cash flow problems (see Nature 349, 551; 14 February 1991), but add that there is "no intention to place any additional financia burden on the universities".

The research council is operating under the assumption that its finances will be in a better state two years from now, and that it will then have no problem honouring the grants in full.

SERC chairman Sir Mark Richmond is determined to protect research grant spending from further cuts. But even with the new policy of spending limits for the first two years of new research projects, SERC expects to award only 50 per cent of the usual number of new research grants this year.

Peter Aldhous

\section{UK RESEARCH FUNDING- \\ Reform may cut grant awards}

\section{London}

The British research councils would have to cut their grant spending in the universities by as much as 12 per cent if the government goes through with a plan to reform British university research funding, according to a confidential report presented last week to Education and Science Secretary Kenneth Clarke.

From the 1992-93 academic year, the government aims to transfer $£ 100$ million a year to the research councils from the research budget of the Universities Funding Council (UFC). The idea is that in the future the research councils will pay the overhead costs (administrative costs, telephone bills and the like) of research projects they support. The universities would then be responsible only for the salaries of permanent academic staff and the costs of running university buildings.

But the new report, prepared by the Committee of Vice-Chancellors and Principals (CVCP) and the research councils, says that $£ 100$ million is inadequate to cover the overhead costs of research council-funded projects. The CVCP calculates that $£ 138$ million is needed; the research councils put the figure at $£ 149$ million. Their analysis is based on the costs of a sample of research projects in ten British universities.
If the research councils are to pay the overhead costs of each project they support but are given only an extra $£ 100$ million to do so, the report argues, they will have little option but to award fewer research grants.

The proposed transfer has not created a new problem - it has merely made more evident the universities' assertion that they have not been getting paid enough for research for some time. "It is clear that some universities have been paying for the direct costs of projects supported by research council grants to a far greater extent ... than has been recognized," the CVCP concludes in the report. And Derek Roberts, provost of University College London, argues that the underfunding of research costs in the universities is some $£ 100$ million more than suggested by the research councils: the report excluded the cost of mainframe computing, and did not consider projects funded by charities.

The report, which was commissioned by the government, should put pressure on the Department of Education and Science (DES) to provide more money for research. But Clarke is not expected to abandon the planned transfer, which has already been delayed by one year. The DES is convinced that the transfer will improve the administration of research spending.

PeterAldhous

\section{Mining ban in the air}

\section{London}

Mining in Antarctica would be banned for at least 50 years if the governments of the Antarctic Treaty nations sign a draft protocol on Antarctic environmental protection produced last week at a meeting in Madrid. But it is not clear whether the Bush Administration in the United States will approve the version of the treaty agreed to by its negotiators, and a rejection of the draft could yet prevent consensus on the divisive mining issue when Antarctic Treaty nations meet next month.

The draft text would ban mining and oil exploration for the next half a century. Even after then, the ban could be relaxed only if all of the present 26 consultative parties to the Antarctic Treaty agree - generally seen as an unlikely prospect.

The protocol has pleased environmentalist groups and those governments, led by Australia and France, that were pushing for a permanent ban. James Martin Jones, from the World Wide Fund for Nature, says agreement on the draft "would give us what could be described as an indefinite ban."

Before the meeting, a group of nations led by Britain and the United States was expected to ensure that the option of mining in the future was kept open. But the group was weakened by a surprise policy reversal by Japan, which was previously a strong supporter of the mining option (see Nature 348, $570 ; 1990)$. The Japanese delegation announced at the start of the meeting that Japan would support a ban that could be lifted only by consensus.

Observers in Madrid now expect the United States to be the only possible obstacle to agreement on the draft protocol. The draft is understood to have gone well beyond the negotiating brief given to Curtis Bohlen, head of the US State Department delegation.

The US administration has until a second meeting in Madrid, beginning on 17 June, to consider the draft. State Department officials last week refused to comment.

Britain, however, is expected to accept the draft. The UK Foreign Office has said that consensus on the mining issue is its number one priority, and rejection of a draft supported by the vast majority of Antarctic nations would be politically embarrassing.

Aside from the mining ban, the draft environmental protocol contains new provisions to assess the environmental impact of proposed research projects in Antarctica. Antarctic scientists had feared that a new regime of environmental impact assessment would place undue restrictions on Antarctic research. Under the new draft, the environmental impact of some research projects will have to be assessed. But this will be carried out by national authorities, and is not expected to place obstacles in the way of research.

Peter Aldhous 